\title{
The expression and regulation of matrix metalloproteinase- 3 is critically modulated by Porphyromonas gingivalis lipopolysaccharide with heterogeneous lipid $A$ structures in human gingival fibroblasts
}

\author{
Thanuja D K Herath', Yu Wang², Chaminda J Seneviratne ${ }^{1}$, Richard P Darveau ${ }^{3}$, Cun-Yu Wang ${ }^{4}$ and Lijian Jin ${ }^{{ }^{*}}$
}

\begin{abstract}
Background: Porphyromonas gingivalis lipopolysaccharide (LPS) is a crucial virulence factor strongly associated with chronic periodontitis which is the primary cause of tooth loss in adults. It exhibits remarkable heterogeneity containing tetra-(LPS $\left.{ }_{1435 / 1449}\right)$ and penta-(LPS 1690$)$ acylated lipid A structures. Human gingival fibroblasts (HGFs) as the main resident cells of human gingiva play a key role in regulating matrix metalloproteinases (MMPs) and contribute to periodontal homeostasis. This study investigated the expression and regulation of MMPs1-3 and tissue inhibitors of MMP-1 (TIMP-1) in HGFs in response to P. gingivalis LPS ${ }_{1435 / 1449}$ and LPS $_{1690}$ and hexa-acylated E. coli LPS as a reference. The expression of MMPs 1-3 and TIMP-1 was evaluated by real-time PCR and ELISA.

Results: The MMP-3 mRNA and protein were highly upregulated in P. gingivalis LPS ${ }_{1690^{-}}$and E. coli LPS-treated cells, whereas no induction was observed in P. gingivalis LPS ${ }_{1435 / 1449}$-treated cells. On the contrary, the expression of MMP-1 and -2 was not significantly affected by $P$. gingivalis LPS lipid A heterogeneity. The TIMP-1 mRNA was upregulated in P. gingivalis LPS $1435 / 1449^{-}$and E. coli LPS-treated cells. Next, signal transduction pathways involved in P. gingivalis LPS-induced expression of MMP-3 were examined by blocking assays. Blockage of p38 MAPK and ERK significantly inhibited $P$. gingivalis LPS $_{1690}$-induced MMP-3 expression in HGFs.

Conclusion: The present findings suggest that the heterogeneous lipid A structures of $P$. gingivalis LPS differentially modulate the expression of MMP-3 in HGFs, which may play a role in periodontal pathogenesis.
\end{abstract}

Keywords: Periodontal disease, P. gingivalis LPS, Lipid A heterogeneity, MMPs, Human gingival fibroblasts

\section{Background}

Periodontal disease is a bacterially induced and highly common chronic inflammatory condition in humans, and severe periodontal disease (periodontitis) remains the major cause of tooth loss in adult population worldwide [1]. Dysregulated host response to pathogenic plaque biofilm critically contributes to destructive inflammation resulting in tissue damage and alveolar bone loss [2]. Porphyromonas gingivalis is a

\footnotetext{
* Correspondence: ljininhkucc.hku.hk

${ }^{1}$ Faculty of Dentistry, Periodontology, The University of Hong Kong 34 Hospital Road, Hong Kong SAR, China

Full list of author information is available at the end of the article
}

keystone periodontal pathogen in the mixed microbial community and it releases copious amount of lipopolysaccharide (LPS) which perpetually interacts with host cells, thereby significantly contributing to periodontal pathogenesis [1-4].

LPS is a potent immuno-inflammatory modulator which causes serious complications in host. It is comprised of three major components viz. outermost $\mathrm{O}$-antigen, core oligosaccharide regions and innermost lipid A [3]. Lipid A is the biologically most active component of LPS that imparts the endotoxin activity. Its structure differs widely among Gram-negative bacteria species depending on the differences in composition
C Biomed Central

(c) 2013 Herath et al.; licensee BioMed Central Ltd. This is an Open Access article distributed under the terms of the Creative Commons Attribution License (http://creativecommons.org/licenses/by/2.0), which permits unrestricted use, distribution, and reproduction in any medium, provided the original work is properly cited. 
of attached fatty acids, number of phosphorylation sites and substituted groups attached to the phosphate residues [3]. The canonical lipid A structure in Escherichia coli LPS is a hexa-acylated diphosphorylated glucosamine disaccharide. Previous studies have shown that $P$. gingivalis possesses highly heterogeneous lipid A structures containing penta-acylated $\mathrm{LPS}_{1690}$ and tetraacylated LPS $_{1435 / 1449}$, and this structural discrepancy may critically account for contrasting biological activities induced by $P$. gingivalis LPS $[3,4]$.

Human gingival fibroblasts (HGFs) are the major cell type in human gingiva [5-7]. They play a key role in maintenance and remodeling of extra cellular matrix (ECM) by producing various structural components, such as collagen, elastin, glycoprotein and glycosaminoglycans. In addition, HGFs also synthesize and secrete various members of matrix metalloproteinases (MMPs) in response to $P$. gingivalis LPS challenge, which ultimately contribute to periodontal tissue destruction [8]. MMPs are a family of structurally and functionally related proteolytic enzymes containing a zinc-binding catalytic domain and they are active against the components of ECM [8-10]. The activity of MMPs is largely regulated by several naturally occurring inhibitors like tissue inhibitors of metalloproteinases (TIMPs) [11]. Overall, there is a remarkable balance between MMPs and TIMPs in periodontal connective tissues and disturbance of this balance is therefore critically implicated in the destruction of periodontal tissues $[12,13]$. In normal conditions, MMPs are involved in the remodeling and turnover of periodontal tissues under the strict control of TIMPs, which bind specifically to the active site of the enzyme thereby maintaining the equilibrium between degradation and regeneration of ECM $[8,14]$. Increased production of MMPs 1-3 is observed in chronic inflammatory condition such as periodontitis that results in excessive connective tissue breakdown [14,15]. MMPs such as MMP-1, -2, -3, - 9 and -13 are synthesized in periodontal tissues in response to periodontopathic bacteria like $P$. gingivalis. Previous studies have suggested that LPS could regulate the MMP expression in various host cell types including HGFs $[10,16]$.

Currently, there are no studies on the role of $P$. gingivalis LPS lipid A heterogeneity with respect to expression of MMPs in HGFs. The present study therefore aimed to investigate the expression and regulation of MMPs 1-3 and TIMP-1 in HGFs in response to the different isoforms of $P$. gingivalis $\mathrm{LPS}_{1435 / 1449}$ and $P$. gingivalis $\mathrm{LPS}_{1690}$ as well as $E$. coli LPS as a reference. This study sheds light on the regulation of MMP expression and underlying signal transduction pathways in HGFs in response to heterogeneous $P$. gingivalis LPS, which could have important implications in the pathogenesis of periodontal disease.

\section{Results}

Heterogeneous $P$. gingivalis LPS lipid A structures differentially modulate MMPs $1-3$ and TIMP-1 mRNAs

The dose-dependent experiments showed that both P. gingivalis $\mathrm{LPS}_{1435 / 1449}$ and $\mathrm{LPS}_{1690}$ differentially modulated the expression of MMP-3 transcript. The latter $(0.1-10 \mu \mathrm{g} / \mathrm{ml})$ markedly upregulated the expression of MMP-3 mRNA while the former did not affect the expression (Figure 1c). Similarly, E. coli LPS $(0.1-10 \mu \mathrm{g} / \mathrm{ml})$ significantly upregulated MMP-3 expression. Both isoforms of $P$. gingivalis LPS upregulated to different extent the expression of MMP-1 and MMP-2 mRNAs, while E. coli LPS significantly upregulated the expression of these transcripts (Figures 1a and b). TIMP-1 mRNA expression was significantly induced in $P$. gingivalis LPS $_{1435 / 1449^{-}}$and E. coli LPS-treated cells, and no significant induction was observed following $P$. gingivalis $\mathrm{LPS}_{1690}$ stimulation (Figure 1d).

Notably, MMP-3 transcript was differentially expressed in the cells treated by the two isoforms of $P$. gingivalis LPS. P. gingivalis LPS $_{1690}$ significantly upregulated MMP3 mRNA expression at 24 and $48 \mathrm{~h}$, while E. coli LPS showed prompt expression at $12 \mathrm{~h}$ (Figure 2c). MMP-2 mRNA was significantly upregulated by both $P$. gingivalis LPS $_{1435 / 1449}$ and LPS 1690 at $48 \mathrm{~h}$ (Figure 2b), and MMP-1 transcript was significantly upregulated by $P$. gingivalis LPS $_{1690}$ (Figure 2a). E. coli LPS significantly upregulated both MMP-1 and MMP-2 mRNA expression. TIMP-1 transcript was differently modulated by $P$. gingivalis $\mathrm{LPS}_{1435 / 1449}$ and LPS 1690 . The former significantly upregulated its expression at 24 and $48 \mathrm{~h}$, so did E. coli LPS at $48 \mathrm{~h}$.

\section{P. gingivalis $\mathrm{LPS}_{1690}$ significantly upregulates MMP-3 protein expression}

Both dose- and time-dependent experiments showed that MMP-3 protein was differentially modulated by P. gingivalis $\mathrm{LPS}_{1435 / 1449}$ and $\mathrm{LPS}_{1690}$ in consistent with its transcript expression profile (Figure 3). P. gingivalis LPS $_{1690}$ at $1 \mu \mathrm{g} / \mathrm{ml}$ and $10 \mu \mathrm{g} / \mathrm{ml}$ significantly upregulated MMP-3 protein expression in a timedependent manner (12-48 h) (Figure 3c). The MMP-3 level detected in the culture supernatant was greatly higher than that in the cellular fraction (Figures 3a and b). Similar observations occurred in E. coli LPS-treated cells. Moreover, the MMP-3 level induced by $P$. gingivalis $\mathrm{LPS}_{1690}$ was significantly greater than that stimulated by P. gingivalis $\mathrm{LPS}_{1435 / 1449}$ (Figures 3a-c).

Next, western blot analysis confirmed that MMP-3 protein markedly increased in $P$. gingivalis $\mathrm{LPS}_{1690^{-}}$and E. coli LPS-treated cells at $48 \mathrm{~h}$, while $P$. gingivalis LPS $_{1435 / 1449}$ did not induce MMP-3 at a notable level (Figures 4a and c). 

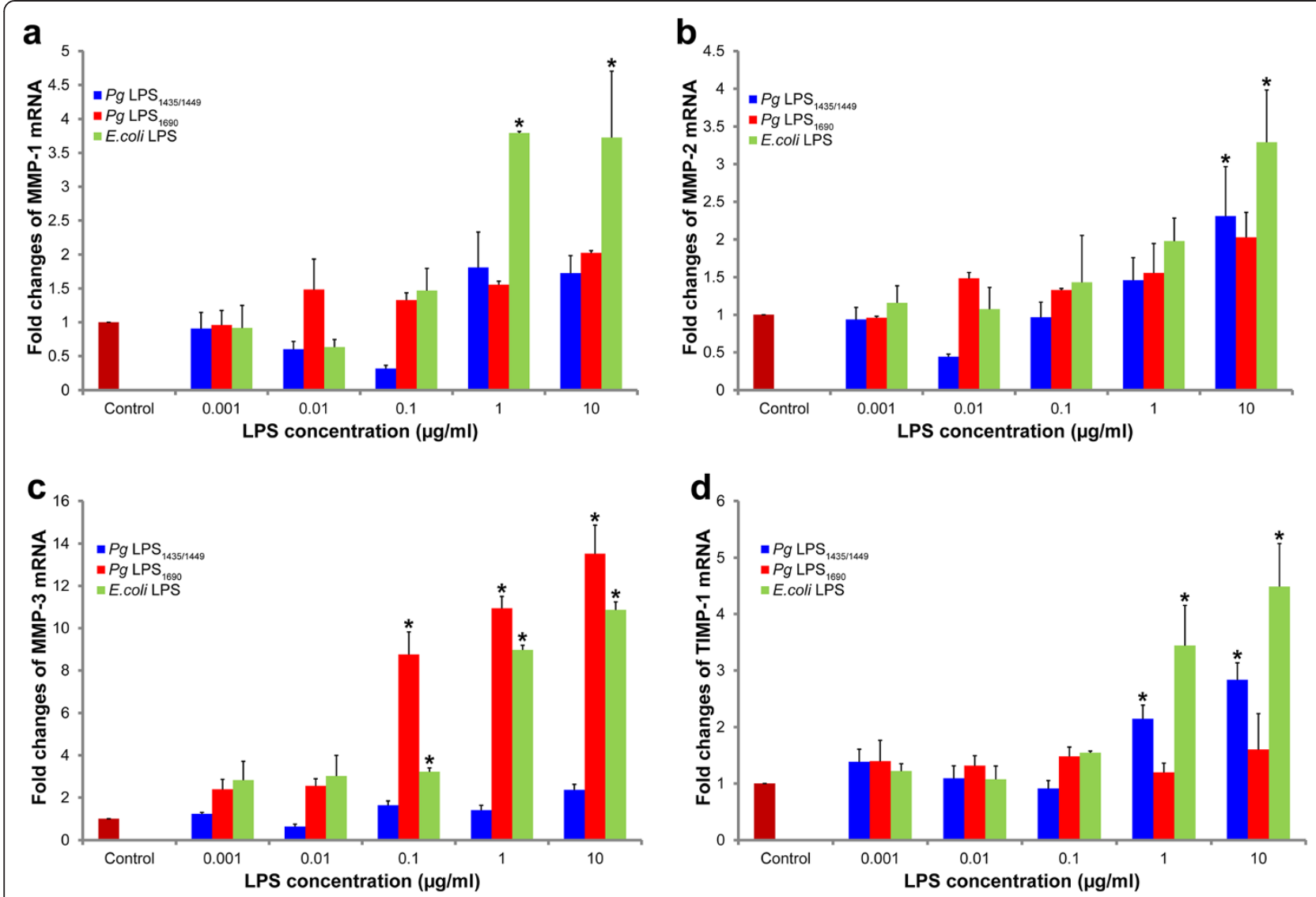

Figure 1 Dose-dependent expression of MMPs 1-3 and TIMP-1 mRNAs in P. gingivalis LPS-treated HGFs. Expression of MMP-1 (a), MMP-2 (b) MMP-3 (c) and TIMP-1(d) mRNAs after the stimulation of $P$. gingivalis (Pg) LPS $\mathbf{1 4 3 5 / 1 4 4 9}$, LPS 1690 and E. coli LPS in a dose-dependent assay $(1 \mathrm{ng} / \mathrm{ml}, 10 \mathrm{ng} / \mathrm{ml}, 100 \mathrm{ng} / \mathrm{ml}, 1 \mathrm{\mu g} / \mathrm{ml}$ and $10 \mu \mathrm{g} / \mathrm{ml}$ ) for $24 \mathrm{~h}$. The expression of mRNAs was measured by real-time qPCR. Each bar represents the mean \pm SD of three independent experiments with three replicates. *Significant difference $(p<0.05)$ as compared with the controls without LPS treatment.

The MMP-2 protein expression is not significantly affected by $P$. gingivalis LPS and $E$. coli LPS

Basal expression of MMP-2 was observed at $24 \mathrm{~h}$, and increased at $48 \mathrm{~h}$ (Figures 4 and 5). With reference to the control, $P$. gingivalis LPS and $E$. coli LPS did not significantly affect the expression levels of MMP-2 proteins (Figures 4a and b). Gelatin zymograms revealed that the MMP-2 presented in two forms including pro-MMP-2 (72 kDa) and active-MMP-2 (68 kDa). In both culture supernatant (Figure $5 \mathrm{a}$ and $\mathrm{b}$ ) and cellular fraction (Figure $5 \mathrm{c}$ and d), the activity of MMP-2 at 24 and 48 h was not significantly affected by $P$. gingivalis LPS and $E$. coli LPS.

\section{P. gingivalis $\mathrm{LPS}_{1690}$ induces MMP-3 expression via MAPK signaling pathway}

Blocking assays were performed to elucidate the involvements of NF-kB and MAPK signaling pathways of $P$. gingivalis $\mathrm{LPS}_{1690}$ induced MMP-3 expression in HGFs. Both ERK inhibitor (U1026) and p38 MAPK inhibitor (SB202190) significantly suppressed the expression levels of MMP-3 transcript (Figure 6a) and protein (Figure 6b) in $P$. gingivalis $\mathrm{LPS}_{1690^{-}}$and $E$. coli LPS-treated cells. Notably, U1026 inhibited MMP-3 expression to a greater extent with reference to SB202190. The expression of MMP-3 was not significantly reduced by IKK-2 inhibitor IV in $P$. gingivalis LPS $_{1690}$-treated cells, whereas it significantly suppressed MMP-3 in E. coli LPS-treated cells (Figure 6).

\section{Discussion}

Periodontal disease is a complex inflammatory disease initiated by pathogenic plaque biofilms and results in destruction of tooth-supporting tissues and alveolar bone $[17,18]$. Proteolytic enzymes like MMPs play a major role in the degradation of collagens in periodontal tissues. The expression and regulation of MMPs and TIMPs in HGFs are therefore crucial for maintenance of tissue homeostasis and periodontal health. Although many studies have been performed to elucidate the mechanisms involved in the synthesis and regulation of MMPs in periodontal research, no studies are available 

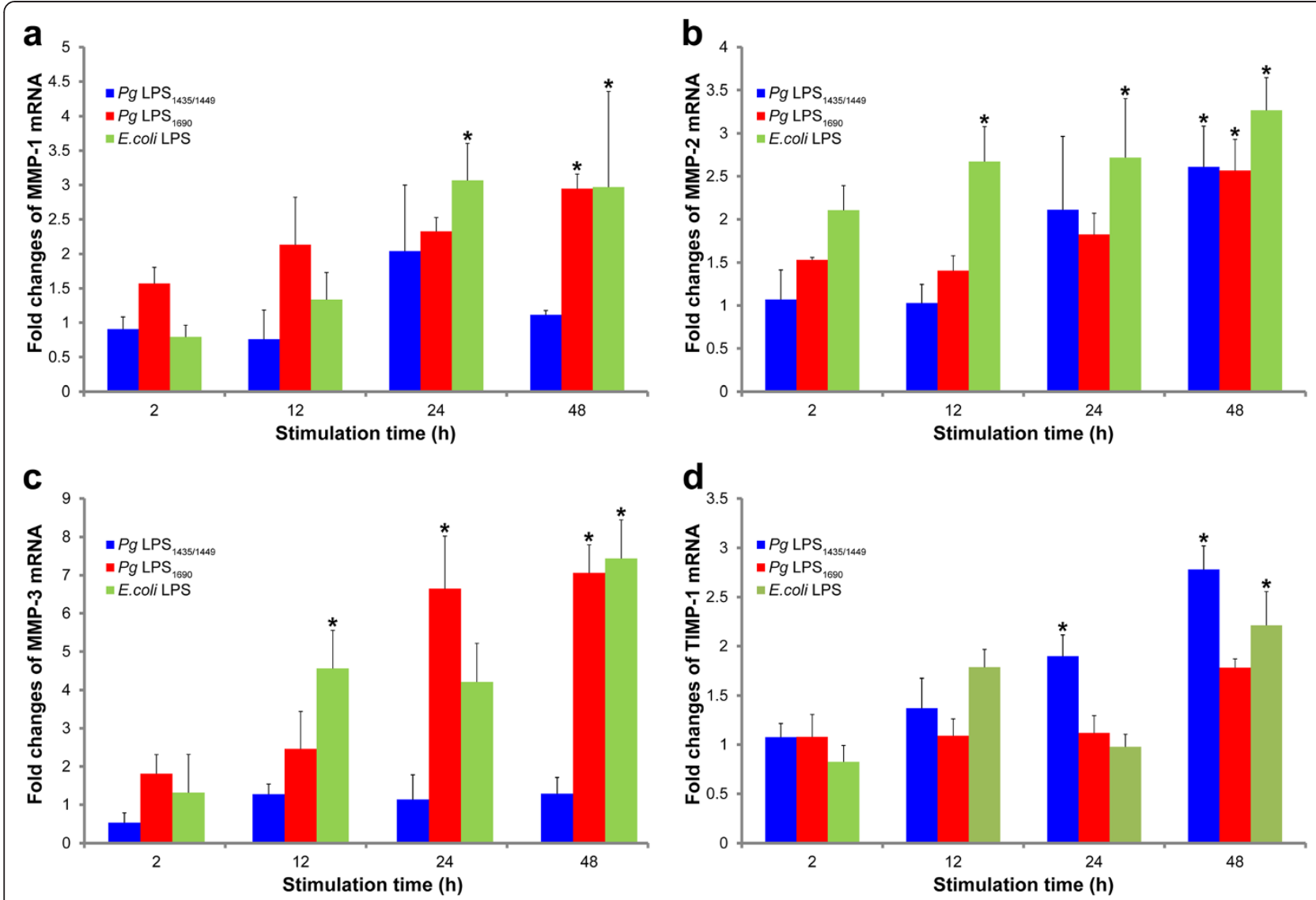

Figure 2 Time-dependent expression of MMPs 1-3 and TIMP-1 mRNAs in P. gingivalis LPS-treated HGFs. Expression of MMP-1 (a), MMP-2 (b) MMP-3 (c) and TIMP-1(d) mRNAs after the stimulation of P. gingivalis (Pg) LPS $1435 / 1449(1 \mu \mathrm{g} / \mathrm{ml}), \mathrm{LPS}_{1690}(1 \mu \mathrm{g} / \mathrm{ml}) \mathrm{and}$ E. coli LPS (1 $\left.\mu \mathrm{g} / \mathrm{ml}\right)$ in a time-dependent assay (2-48 h). The expression of mRNAs was measured by real-time qPCR. Each bar represents the mean \pm SD of three independent experiments with three replicates. *Significant difference $(p<0.05)$ as compared with the controls without LPS treatment.

on the effect of $P$. gingivalis LPS structural heterogeneity on the expression of MMPs and the underlying regulatory mechanisms.

MMP-3 is known as stromelysin which has both elastinolytic and collagenolytic activities that degrade basement membrane components such as laminin, elastin fibronectin as well as collagen types II, III, IV, V, IX, $\mathrm{X}$ and $\mathrm{XI}[8,19]$. Its level could significantly increase following the stimuli of pro-inflammatory cytokines, growth factors and LPS [14,20-22]. It has been shown that HGFs could upregulate the expression of MMP-3 due to the effects of pro-inflammatory cytokines such as IL-1 $\beta$ and TNF- $\alpha$ [23-25]. The current study showed that the expression of MMP-3 mRNA and protein was markedly upregulated by $P$. gingivalis $\mathrm{LPS}_{1690}$, whereas no induction was observed in cells treated with $P$. gingivalis LPS $_{1435 / 1449}$, indicating that the heterogeneous lipid A structures of $P$. gingivalis LPS may differentially modulate the expression of MMP-3 in HGFs. Moreover, TIMP-1 expression was differently modulated by the two isoforms of $P$. gingivalis LPS as well. It functions as an inhibitor of
MMPs by forming non-covalent complexes with MMPs. It has recently been shown that MMP-3 and TIMP-1 variants may significantly contribute to chronic periodontitis and disease progression [26]. The imbalance between MMPs and TIMPs has been implicated in periodontal tissue destruction [27].

$P$. gingivalis has long been recognized as a major periodontopathogen [28]. Recently, it is regarded as a keystone pathogen due to its ability to significantly influence the oral microbial community by modulating the innate host response [29,30]. Moreover, this bacterium adopts multiple pathogenic mechanisms to evade or subvert the host immune system [31-33]. Notably, $P$. gingivalis LPS exhibits significant structural heterogeneity with both isoforms of $\mathrm{LPS}_{1435 / 1449}$ and $\mathrm{LPS}_{1690}$, and our recent studies show that they differentially affect the innate host defense and underlying signaling pathways, thereby contributing to the pathogenesis of periodontal disease $[4,34,35]$. The current observation that the different isoforms of $P$. gingivalis LPS modulate the expression of MMP-3 and TIMP-1 may represent an 

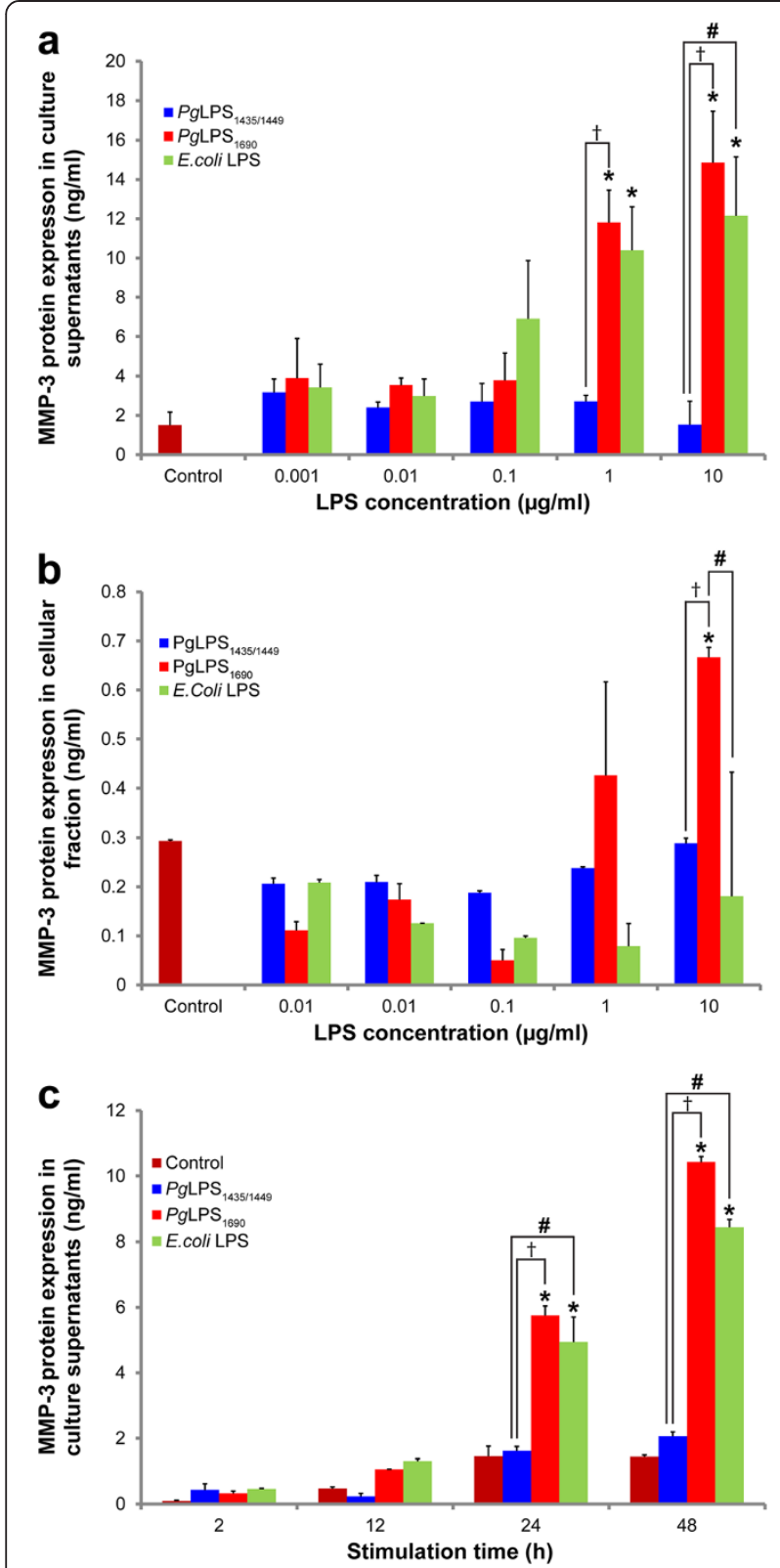

Figure $3 P$. gingivalis $\operatorname{LPS}_{1690}$ significantly upregulates the expression of MMP-3 proteins. Expression of MMP-3 proteins in the culture supernatants (a) and cellular fractions (b) of HGFs after the stimulation of $P$. gingivalis $(\mathrm{Pg}) \mathrm{LPS}_{1435 / 1449}, \mathrm{LPS}_{1690}$ and $E$. coli LPS in a dose-dependent assay $(1 \mathrm{ng} / \mathrm{ml}, 10 \mathrm{ng} / \mathrm{ml}, 100 \mathrm{ng} / \mathrm{ml}$, $1 \mu \mathrm{g} / \mathrm{ml}$ and $10 \mu \mathrm{g} / \mathrm{ml}$ ) for $24 \mathrm{~h}$. Time-dependent expression of MMP-3 proteins in the culture supernatants (c) of HGFs after the stimulation of $P$. gingivalis $\operatorname{LPS}_{1435 / 1449}(1 \mu \mathrm{g} / \mathrm{ml}), \operatorname{LPS}_{1690}(1 \mu \mathrm{g} / \mathrm{ml})$ and E. coli LPS $(1 \mu \mathrm{g} / \mathrm{ml})$ for $2-48 \mathrm{~h}$. The protein expression levels were measured by ELISA. Each bar represents the mean \pm SD of two independent experiments with three replicates. Significant difference as compared with the controls without LPS treatment, ${ }^{*} p<0.05$. Significant difference between the cells treated with $P$. gingivalis $\mathrm{LPS}_{1435 / 1449}$ and LPS 1690 respectively, ${ }^{\dagger} p<0.05$. Significant difference between the cells treated with $P$. gingivalis LPS and E. coli LPS respectively, $" \not p<0.05$. additional pathogenic mechanism adopted by this noxious species to disturb the physiological tissue remodeling and tissue homeostasis, leading to the initiation of periodontal disease.

P. gingivalis and its virulence attributes such as LPS can stimulate various cells types to secrete MMPs including MMP-3 [36,37]. On the contrary, some studies have suggested that $P$. gingivalis LPS may not induce MMPs such as MMP-1, -2 and -9 [38]. A study performed on gingival epithelial cells using $P$. gingivalis LPS and E. coli LPS showed that neither LPS nor IL-1 $\beta$ induced MMP-2 or MMP-9 [39]. Studies on tissue models such as synovial membranes dissected from rat knee joints showed induction of MMP-1, -3 and -9 mRNA levels but not MMP-2 in response to LPS stimulation [40]. However, foregoing studies have not considered the heterogeneous nature of bacterial LPS lipid A structures. Therefore, the conflicting findings of the previous studies could to some extent be due to different isoforms of $P$. gingivalis LPS as demonstrated in the present study.

In the present study, E. coli LPS-treated HGFs exhibited rapid and significant induction of MMPs 1 and 2 mRNAs with reference to the cells treated with $P$. gingivalis LPS $_{1690}$. One possibility for this observation may be the higher responsiveness of HGFs to hexaacylated nature of the E. coli LPS as compared to the penta-acylated structure of $P$. gingivalis LPS $_{1690}$. This notion is consistent with previous findings that $E$. coli LPS is a potent inducer of the production of MMPs in fibroblast-like synovial cells and rat chondrocytes, as well as other innate host response molecules in HGFs and gingival/oral epithelia [41,42]. Moreover, it was noted that both $P$. gingivalis $\operatorname{LPS}_{1435 / 1449}$ and $E$. coli LPS significantly upregulated the expression of MMP-2 mRNA but not its protein as compared to the controls. A number of factors may account for this finding, such as the stability of mRNA, its processing and splicing patterns, half-life of the target protein and posttranslational modifications $[43,44]$. Therefore, in the present study increase in MMP-2 mRNA expression level may not be necessarily reflected at its protein level.

TIMPs exhibit high affinity for binding with MMPs and lead to inhibition of their activities. In the present study, TIMP-1 mRNA was upregulated by $P$. gingivalis LPS $_{1435 / 1449}$-treated HGFs, while no significant upregulation was observed in $P$. gingivalis $\mathrm{LPS}_{1690}$-stimulated cells. The current results may not be comparable with previous studies in which the structural heterogeneity of LPS was not fully considered [45-49]. This omission may account for the conflicting reports in the literature. Hence, some studies have observed lower TIMP-1 levels in the conditioned media of HGFs in 


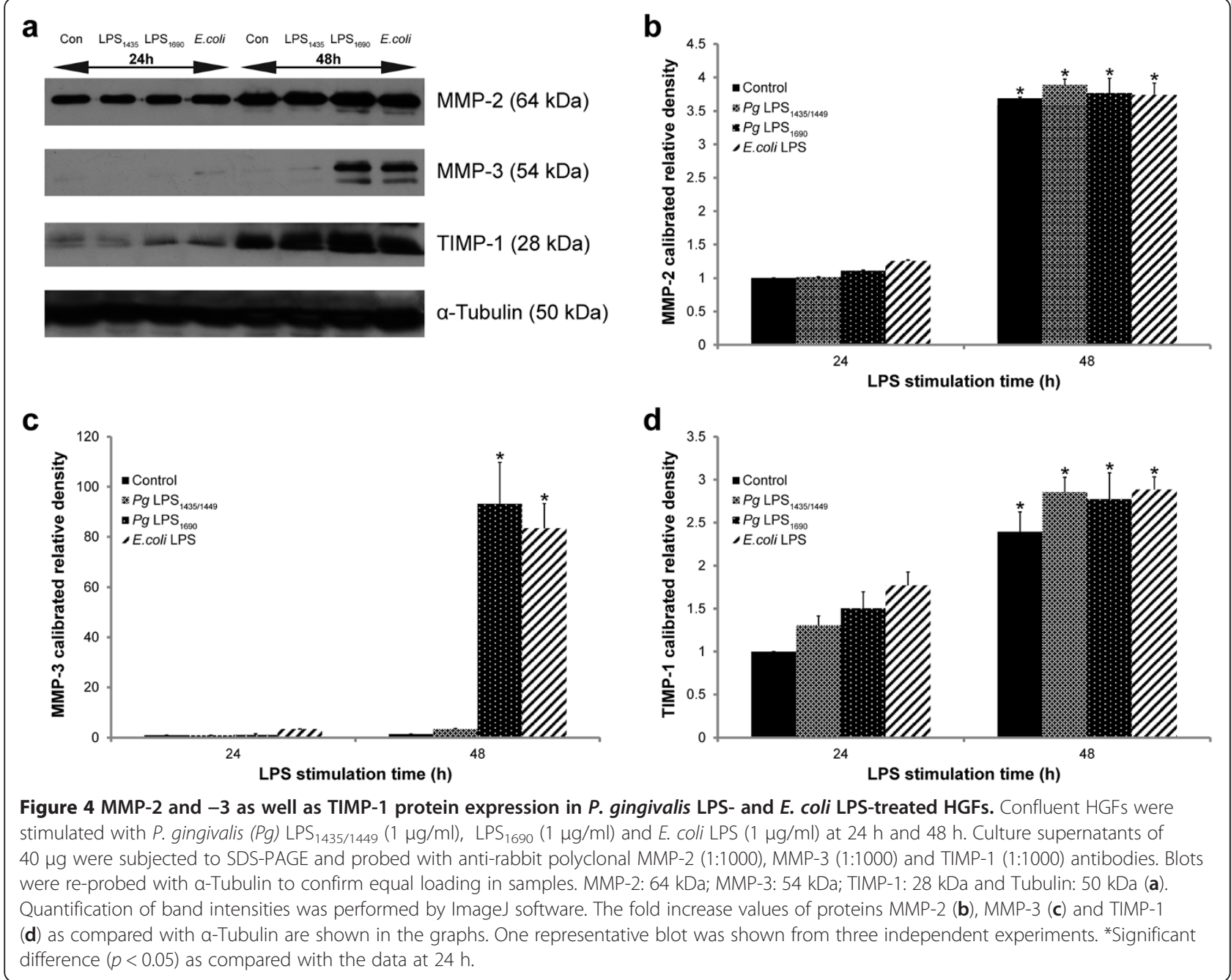

response to $P$. gingivalis LPS [49]. In contrast, other studies have noted the increased expression level of TIMP-1 in gingival crevicular fluid of periodontitis patients [45,47]. Moreover, periodontal treatment could alter the balance between MMP-3 and TIMP-1 [46,48]. Based upon the current findings, further study may be warranted to explore the association of different isoforms of $P$. gingivalis LPS with periodontal conditions in periodontal patients and the possible effect of periodontal treatment on the expression of these LPS isoforms by $P$. gingivalis. In addition, the discrepancy observed in TIMP-1 mRNA and protein expression following the stimulation of both $P$. gingivalis LPS $_{1435 / 1449}$ and E. coli LPS in HGFs could be due to the complex regulation of transcription and translation $[43,44]$.

LPS is the major immuno-stimulatory component of $P$. gingivalis which has shown to be capable of interacting with TLRs. Binding of LPS to TLRs activates the downstream signal transduction pathways such as NF-kB and MAPK [50,51]. Previous studies have suggested that the activation of MMPs could be through both NF-kB and MAPK signaling [23,52-54]. The present study demonstrated that p38 MAPK and ERK are critically involved in $P$. gingivalis $\mathrm{LPS}_{1690^{-}}$and $E$. coli LPS-induced expression of MMP-3 in HGFs. This finding is supported by a previous study that p38 MAPK and ERK1/2 pathways are essential for the expression and regulation of MMPs in various cell types in response to LPS [54]. ERK, JNK and p38 MAPK pathways play vital roles in regulating the expression of MMPs induced by various stimulants such as cytokines $[53,55,56]$. It is noteworthy that the nature of the stimuli could result in specific signal transduction pathway in the same cell type. For instance, MAPK inhibitor significantly reduced the MMP-3 production in HGFs stimulated with IL-1 $\beta$, but not with epidermal growth factor [23]. In addition, NF- $\mathrm{kB}$ pathway may be involved in regulation of MMP-3 expression in rabbit dermal fibroblasts, human saphenous vein and rabbit aortic smooth muscle cells $[57,58]$. The present study showed that NF- $\mathrm{kB}$ signaling is not 

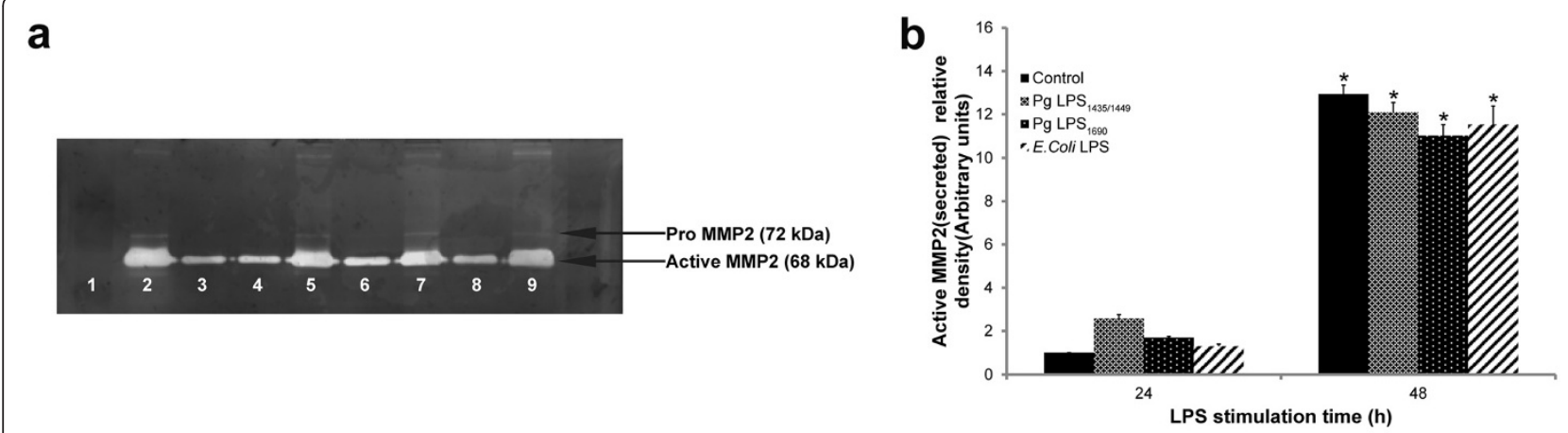

C

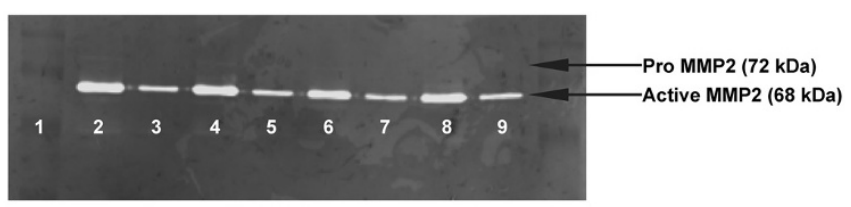

d

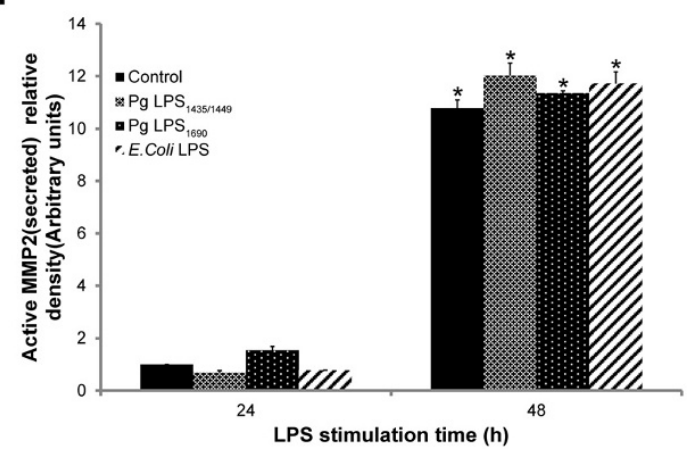

Figure 5 Detection of MMP-2 in supernatant (a) and cellular fraction (c) of HGFs by gelatin zymography and molecular weight positions of pro-MMP-2 (72 kDa) and active-MMP-2 (68 kDa). 5a: Lane1: molecular weight marker; Lane 2: untreated conditioned medium at 48 h; Lane 3: untreated conditioned medium at 24 h; Lanes 4-5: P. gingivalis (Pg) LPS $1435 / 1449$-treated culture medium at $24 \mathrm{~h}$ and $48 \mathrm{~h}$; Lanes 6-7: P. gingivalis LPS 1690 -treated medium at $24 \mathrm{~h}$ and $48 \mathrm{~h}$; Lanes 8-9: E. coli LPS-treated culture medium at $24 \mathrm{~h}$ and $48 \mathrm{~h}$, respectively. $5 \mathrm{c}$ : Lane1: Marker; Lanes 2-3: untreated cellular component at $48 \mathrm{~h}$ and $24 \mathrm{~h}$; Lanes 4-5: P. gingivalis (Pg) LPS $1435 / 1449$-treated cellular component at $48 \mathrm{~h}$ and $24 \mathrm{~h}$; Lanes 6-7: P.gingivalis LPS $1690^{-}$treated cellular component at $48 \mathrm{~h}$ and $24 \mathrm{~h}$; Lanes 8-9: E-coli LPS-treated cellular component at $48 \mathrm{~h}$ and $24 \mathrm{~h}$, respectively. Quantification of band intensities was performed by densitometry analysis using ImageJ software. The fold increase values of MMP-2 in culture supernatant (b) and cellular fraction (d) as compared with the control are shown. *Significant difference $(p<0.05)$ as compared with the data at $24 \mathrm{~h}$.

critically involved in LPS-induced MMP-3 expression in HGFs. Notably, the MAPK pathway but not NF-kB was significantly involved in the regulation of MMP-3 expression in HGFs in both mRNA and protein levels. Previous studies have also proven that the expression of MMP-3 is mainly mediated through P38 MAPK, ERK and tyrosine kinase pathways, but not through NF- $\mathrm{BB}$ pathway $[23,59,60]$. Moreover, although a study reported that the activation of NF- $\mathrm{kB}$ could be important for MMP-3 secretion, no consensus NF- $\mathrm{kB}$ binding site was identified in the MMP-3 gene promoter [61,62]. It suggests that $\mathrm{NF}-\mathrm{kB}$ may regulate the expression of this gene through different binding sites or interacting with other transcription factors [59]. Therefore, within the context and limitations of the present study, it is tempting to speculate that MAPK pathway may be crucial for MMP-3 expression in HGFs in response to $P$. gingivalis $\mathrm{LPS}_{1690}$. Furthermore, it would be interesting to extend the study to other cells types in human gingiva like gingival epithelial cells to ascertain whether MAPK pathway plays a predominant role in the expression and regulation of MMP-3 in other cells of oral tissues.

\section{Conclusions}

The present study reveals that HGFs significantly express MMP-3 in response to penta-acylated P. gingivalis LPS $_{1690}$ and hexa-acylated E. coli LPS, but not to the tetra-acylated $P$. gingivalis LPS $_{1435 / 1449}$ in HGFs. Blocking p38 MAPK and ERK pathways significantly downregulates $P$. gingivalis $\mathrm{LPS}_{1690^{-}}$and $E$. coli LPS-induced expression of MMP-3. These findings indicate that the heterogeneous lipid A structures of $P$. gingivalis LPS differentially modulate the expression of MMP-3 in HGFs, which may play a role in periodontal pathogenesis.

\section{Methods}

Preparation, purification and identification of $P$. gingivalis LPS

$P$. gingivalis LPS was isolated from $P$. gingivalis ATCC 33277 (the American Type Culture Collection, Rockville, 

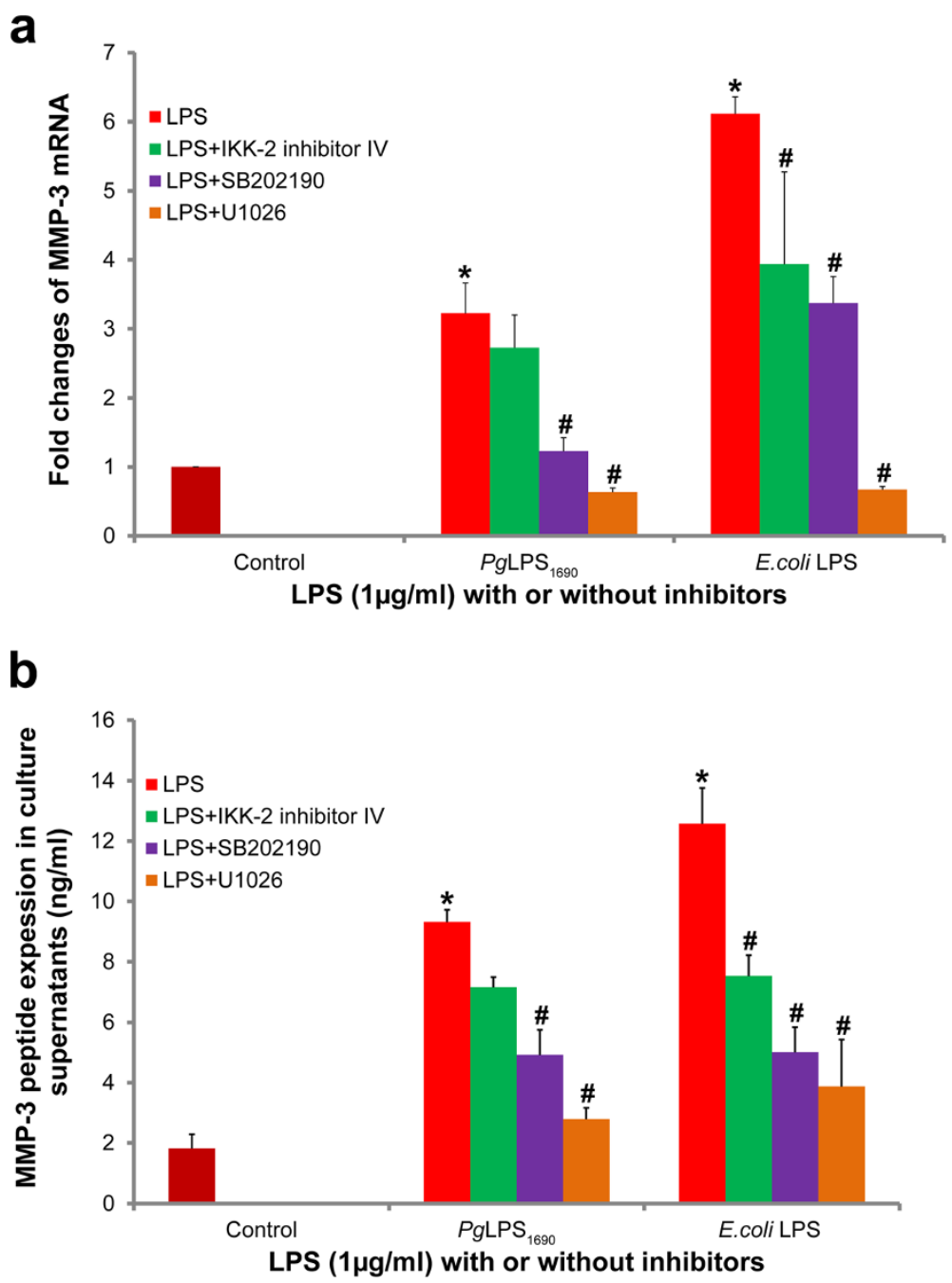

Figure 6 Effects of NF-KB and MAPK inhibitors on P. gingivalis LPS $1690^{-i n d u c e d ~ M M P-3 ~ m R N A ~(a) ~ a n d ~ p r o t e i n ~(b) ~ e x p r e s s i o n ~ i n ~ H G F s . ~}$ Cells were pretreated with IKK-2 inhibitor IV (NF-KB inhibitor), SB202190 (p38 MAPK inhibitor) and U1026 (ERK inhibitor) in serum free medium for $1 \mathrm{~h}$, and then treated with P. gingivalis $(P g) \operatorname{LPS}_{1690}(1 \mu \mathrm{g} / \mathrm{ml})$ and E. coli LPS $(1 \mu \mathrm{g} / \mathrm{ml})$ for additional $12 \mathrm{~h}$. Total RNA was harvested and MMP-3 mRNA levels were determined by real-time qPCR. Cell culture supernatants were collected and the protein expression level was measured by ELISA. The histogram shows quantitative representations of the MMP-3 mRNA levels of three independent experiments. Each value represents the mean \pm SD. *Significant difference $(p<0.05)$ as compared with the controls. "Significant difference $(p<0.05)$ as compared with the cells treated with $P$. gingivalis $L P S_{1690}$ or E. coli LPS alone.

$\mathrm{MD})$. LPS was prepared by the cold $\mathrm{MgCl}_{2}$-Ethanol procedure followed by lipid extraction and conversion to sodium salts as previously described [63,64]. Optical densities were measured at $280 \mathrm{~nm}$ and $260 \mathrm{~nm}$ to verify the nucleic acid and protein contamination. LPS preparations were further treated to remove the endotoxin protein and the final protein contamination was less than $0.1 \%$ [65]. The fatty acid composition of $P$. gingivalis LPS was further analysed by Gas chromatographic-mass spectroscopy. Then two separate extractions of $P$. gingivalis LPS with tetra- $\left(\mathrm{LPS}_{1435 / 1449}\right)$ and pentaacylated $\left(\mathrm{LPS}_{1690}\right)$ lipid A structures were generated, and their structures were verified by matrix-assisted laser desorption ionization time-of-flight mass spectrometry. The canonical hexa-acylated LPS of Escherichia coli JM 83-wild type strain was used as the reference [66].

\section{Cell culture}

HGFs were obtained from Sciencell research laboratories (Carlsbad, CA, USA) and cultured according to the manufacturer's instructions $[67,68]$. Continuous subcultures up to 10th passage contained homogeneous, slim and spindle-shaped cells growing in characteristic swirls. Third to fourth passages of HGFs without any signs of senescence were used for all experiments as described in our previous study [4]. 
Table 1 Nucleotide sequence of real-time qPCR primers

\begin{tabular}{ll}
\hline Primers & Sequence $\left(\mathbf{5}^{\prime}\right.$ - $\left.\mathbf{3}^{\prime}\right)$ \\
\hline MMP1-F & ATG CTG AAA CCC TGA AGG TG \\
MMP1-R & CTG CTT GAC CCT CAG AGA CC \\
MMP2-F & AGG GCA CAT CCT ATG ACA GC \\
MMP2-R & ATT TGT TGC CCA GGA AAG TG \\
MMP3-F & GCA GTT TGC TCA GCC TAT CC \\
MMP3-R & GAG TGT CGG AGT CCA GCT TTC \\
TIMP1-F & CTG TTG TTG CTG TGG CTG AT \\
TIMP1-R & TCC GTC CAC AAG CAA TGA GT \\
$\beta$-actin -F & TTG GCA ATG AGC GGT T \\
$\beta$-actin -R & AGTTGAAGGTAGTTTCGTGGAT \\
\hline
\end{tabular}

Stimulation of HGFs by heterogeneous $P$. gingivalis LPS

The cells suspended at $10^{5} \mathrm{cell} / \mathrm{ml}$ were seeded on sixwell-plates and grown until confluent at $37^{\circ} \mathrm{C}$ with $5 \%$ $\mathrm{CO}_{2}$ in a culture medium for fibroblasts consisting of basal medium with $2 \%$ fetal bovine serum, penicillin/ streptomycin $(0.01 \% \mathrm{w} / \mathrm{v})$ and fibroblast growth supplement. Once the cells were over $90 \%$ confluent, fibroblast medium (FM) was replaced entirely with serum free and animal component free-medium (FM-acf) for the doseand time-dependent experiments. In the dose-dependent assay, cells were stimulated with $P$. gingivalis LPS $_{1435 / 1449}$, $P$. gingivalis $\mathrm{LPS}_{1690}$ or $E$. coli LPS in the media containing various doses of LPS $(0.001 \mu \mathrm{g} / \mathrm{ml}-10 \mu \mathrm{g} / \mathrm{ml})$. Subsequently, $1 \mu \mathrm{g}$ of LPS was selected as the appropriate dose for the following time-dependent experiments. Cells were incubated with $P$. gingivalis LPS or $E$. coli LPS at $1 \mu \mathrm{g} / \mathrm{ml}$ and harvested at 2, 12, 24 and $48 \mathrm{~h}$. Cells without LPS treatment were designated as the controls. Culture supernatants were collected and centrifuged to remove the cellular debris and stored at $-70^{\circ} \mathrm{C}$ for subsequent protein assays. Cellular fraction was then washed with PBS and collected for mRNA and protein extraction.

\section{RNA extraction, cDNA synthesis and real-time qPCR}

Total RNA extraction, cDNA transcription and real-time qPCR for MMPs1-3 and TIMP-1 were performed as previously described [17]. In brief, total RNA was extracted from the homogenized HGFs using RNeasy Mini Kit (Qiagen, Hilden, Germany) according to the manufacturer's instructions [35]. cDNA was synthesized by reverse transcriptase-PCR at $43^{\circ} \mathrm{C}$ for $90 \mathrm{~min}$ in a $20 \mu \mathrm{l}$ of reaction mixture containing $1 \mu \mathrm{g}$ of total RNA, $1 \mu \mathrm{l}$ (200 U) of SuperScript ${ }^{\mathrm{TM}}$ First-Strand Synthesis System (Invitrogen Corp., Carlsbad, CA, USA), $0.5 \mu \mathrm{g}$ of oligo dT-primer, first-strand buffer, $10 \mathrm{mM}$ DTT, and $1 \mathrm{mM}$ dNTPs. A control reaction was performed without reverse transcriptase for all samples to verify the absence of genomic DNA contamination. Real-time qPCR was then performed by using the StepOne Real-Time PCR
System (Applied Biosystems, Foster City, CA) in at least three separate experiments. Amplification reactions were undertaken in $20 \mu \mathrm{l}$ of reaction mixture containing $10 \mu \mathrm{l}$ of Power SYBR ${ }^{\circledR}$ Green PCR Master Mix, $1 \mu$ l of cDNA template and $1 \mu \mathrm{l}$ of each pair of primers for the targeting cytokine genes (Sigma, St. Louis, MO, USA). Real-time primer pairs were designed using ABI software to amplify a sequence that contains two or more exons whenever possible. The amplification efficiencies of the primers used were above $90 \%$. The specific sequences for each pair of primers are listed in Table 1. $\beta$-actin was amplified as an internal control. The real-time qPCR reaction conditions were set at $95^{\circ} \mathrm{C}$ for $10 \mathrm{~min}$ followed by 40 cycles at $95^{\circ} \mathrm{C}$ for $15 \mathrm{~s}$ and $60^{\circ} \mathrm{C}$ for $60 \mathrm{~s}$. The results were analyzed using the comparative cycle threshold (Ct) method as previously described [35]. The expression level of each gene was normalized to a $\beta$-actin $(\Delta C t)$ and the fold changes for each gene were calculated by comparing the test and control samples from the $\Delta \Delta \mathrm{Ct}$ values.

Total protein extraction and detection of MMP-3 by ELISA Total proteins were extracted from homogenized HGFs using CellLytic ${ }^{\mathrm{TM}}$ MT-mammalian cell lysis extraction reagent (Sigma, USA). Protein concentrations in both of the cell-bound fraction and culture supernatant were measured respectively by BCA protein assay kit (Pierce, Thermo Scientific, USA) according to the manufacturer's instructions. Enzyme-linked immunosorbent assay (ELISA) was performed to confirm the expression of MMP-3 proteins (BioRad Laboratories, Hercules, CA, USA). The protein expression in both cell lysate and culture supernatants were measured following manufacturer's instruction with the minimal detectable concentration of $0.009 \mathrm{ng} / \mathrm{ml}$. No cross reactivity or no interference was observed with recombinant MMP-3. The absorbance values were determined by a micro-plate reader (Victor, Vienna, VA, USA) at optical absorbance of $450 \mathrm{~nm}$ and the final concentration was determined with reference to a standard curve. Experiments were repeated two times with three biological replicates.

\section{Western blot analysis for MMP-2, -3 and TIMP-1 proteins} Total cell lysates were prepared and $40 \mu \mathrm{g}$ of cellular extracts were separated by $10 \%$ SDS-PAGE gel and subsequently transferred onto a polyvinylidene difluoride membrane (PVDF). The proteins were then blocked against the protein-free blocking buffer (Pierce, Thermo Scientific) for $1 \mathrm{~h}$. Afterwards, membranes were incubated overnight at $4^{\circ} \mathrm{C}$ with primary antibodies against polyclonal rabbit anti-human IgG; MMP-2 (1:1000; Cell signaling), MMP-3 (1:1000; BioVendor) and TIMP-1 (1:1000; Cell signaling), and incubated with horseradish peroxidase (HRP) conjugated anti-rabbit secondary antibodies 
(1:10000). Visualization of the immunoreactive proteins were accomplished by the use of SuperSignal West Pico Chemiluminescent Substrate (Thermo Scientific, Rockford, IL, USA) and exposed to X-ray films. $\alpha$-Tubulin was used as the internal loading control (1:1000; Cell signaling). The detected bands were scanned on a calibrated densitometer, GS-800 and assessed by the imageJ software-based analysis (http://rsb.info.nih.gov/ij/) to quantify the integrated density.

\section{Gelatin zymography for enzymatic activity of MMP-2}

SDS-PAGE gelatin zymography was performed to observe the enzymatic activity of MMP-2. Supernatants and cellular proteins were collected from cells grown in serum-free medium at $24 \mathrm{~h}$ and $48 \mathrm{~h}$ as described above. Centrifugal filter devices (Amicon Ultra-0.5-Millipore USA) with a cut off value of 30000 NMWL (Nominal Molecular Weight Limit) were used to concentrate the supernatants. Culture supernatants or cellular extracts $(40 \mu \mathrm{g})$ were mixed with $2 \times$ non-reducing sample buffer without $\beta$-mercaptoethanol $(0.125 \mathrm{M}$ Tris- $\mathrm{HCl}$ at $\mathrm{pH} 6.8$, $4 \%$ SDS, $20 \%$ glycerol and $0.05 \%$ bromophenol blue). Proteins were separated by $10 \%$ Tris-glycine polyacrylamide gel copolymerized with $0.1 \%$ gelatin as a substrate. After electrophoresis, gels were washed in renaturation buffer (2.5\% Triton $\mathrm{X}-100$ in $50 \mathrm{mM}$ Tris- $\mathrm{HCl}$ at $\mathrm{pH} 7.5)$ for $1 \mathrm{~h}$ and incubated for $20 \mathrm{~h}$ at $37^{\circ} \mathrm{C}$ in incubation buffer (0.15 M NaCl, $10 \mathrm{mM} \mathrm{CaCl} 2$ and $0.02 \% \mathrm{NaN} 3$ in $50 \mathrm{mM}$ Tris- $\mathrm{HCl}$ at $\mathrm{pH}$ 7.5). Gels were stained with $5 \%$ Coomassie blue and destained with 7\% methanol and 5\% acetic acid to reveal zones of lysis within the gelatin matrix. Areas of enzymatic activity appeared as clear bands over the dark background.

\section{Signal transduction pathways involved in LPS-induced MMP-3 expression in HGFs}

Specific pharmacological inhibitors for NF-kB activity, IKK- $\beta$ inhibitor (IKK-2 inhibitor IV), p38 MAPK activity (SB202190) and ERK activity (U1026) were used to investigate two major signaling pathways potentially involved in the expression and regulation of MMP-3 in HGFs in response to heterogeneous $P$. gingivalis LPS. Each inhibitor was first dissolved in dimethyl sulfoxide (DMSO) and diluted in DPBS. Cells were pretreated with kinase inhibitors, including $10 \mu \mathrm{mol} / \mathrm{L}$ of IKK-2 inhibitor IV (Merck, USA), $10 \mu \mathrm{mol} / \mathrm{L}$ of SB202190 (Calbiochem Biosciences Inc, La Jolla, CA, USA) and $15 \mu \mathrm{mol} / \mathrm{L}$ of U1026 (Cell Signaling, USA) respectively for one hour, prior to stimulation with LPS. Afterwards, $1 \mu \mathrm{g} / \mathrm{ml}$ of LPS was added to the medium and cells were incubated for another $12 \mathrm{~h}$. Culture supernatants were collected for analyzing the MMP-3 expression by ELISA. Extracted RNA was subjected to real-time qPCR to detect the MMP-3 transcript expression. Positive controls were the supernatants from the cells treated with LPS alone, whereas the negative controls were incubated with the culture medium alone. In addition, the cells treated with DMSO alone were considered as the vehicle control (data not shown).

\section{Statistical analysis}

All experiments were repeated in three assays for realtime qPCR and two assays for ELISA. Results of the experiments were presented as the mean \pm SD. The statistical significance of difference between the data sets from the dose-dependent assay was evaluated by student t-test, one-way analysis of variance (ANOVA) and post hoc testing with Bonferroni and LSD methods. Additionally, the repeated-measures of ANOVA were used to determine the differences between data sets from the time-dependent assay. A $p$-value $<0.05$ was considered statistically significant. All statistical analysis was performed using a software program (SPSS 19.0, SPSS Inc, Chicago, IL, USA).

\section{Abbreviations}

Pg: P. gingivalis; LPS: Lipopolysaccharides; HGFs: Human gingival fibroblasts; MMPs: Matrix metalloproteinases; TIMP: Tissue inhibitors of metalloproteinases; qPCR: Quantitative PCR; ELISA: Enzyme linked immunosorbent assay; NF-kB: Nuclear factor-kappaB; MAPK: Mitogenactivated protein kinase.

\section{Competing interests}

The authors declare that they have no competing interests.

\section{Authors' contributions}

TDKH, CJS and LJJ conceived the study. RPD carried out the preparation, purification and identification of $P$. gingivalis LPS. TDKH and CJS performed the cell culture of HGFs, RNA extraction, CDNA synthesis and real-time GPCR, ELISA, Western blot, gelatin zymography, and detection of signal transduction pathways. RPD, CYW, YW and LJJ were involved in supervision of the experiments and provided reagents and materials. TDKH, CJS and LJ analyzed the data, and wrote the manuscript. All authors read and approved the final manuscript.

\section{Acknowledgements}

The authors are grateful to Mr. Alan Wong and Ms. Becky Cheung from the Centralized Research Laboratory at the Faculty of Dentistry, The University of Hong Kong, for their technical assistance. This study was financially supported by the Hong Kong Research Grants Council (HKU766909 M, HKU768411 M and HKU767512 M to LJJ) and the Modern Dental Laboratory/ HKU Endowment Fund to LJJ.

\section{Author details}

${ }^{1}$ Faculty of Dentistry, Periodontology, The University of Hong Kong 34 Hospital Road, Hong Kong SAR, China. ${ }^{2}$ Department of Pharmacology and Pharmacy, Faculty of Medicine, The University of Hong Kong Hong Kong SAR, China. ${ }^{3}$ School of Dentistry, University of Washington Seattle, WA, USA.

${ }^{4}$ School of Dentistry, University of California Los Angeles, CA, USA.

Received: 13 November 2012 Accepted: 15 March 2013

Published: 30 March 2013

\section{References}

1. Jin LJ, Armitage GC, Klinge B, Lang NP, Tonetti M, Williams RC: Global oral health inequalities: task group-periodontal disease. Adv Dent Res 2011, 23:221-226

2. Darveau RP: Periodontitis: a polymicrobial disruption of host homeostasis. Nat Rev Microbiol 2010, 8:481-490. 
3. Dixon DR, Darveau RP: Lipopolysaccharide heterogeneity: innate host responses to bacterial modification of lipid a structure. J Dent Res 2005, 84:584-595.

4. Herath TD, Wang Y, Seneviratne CJ, Lu Q, Darveau RP, Wang CY, Jin L: Porphyromonas gingivalis lipopolysaccharide lipid a heterogeneity differentially modulates the expression of IL-6 and IL-8 in human gingival fibroblasts. J Clin Periodontol 2011, 38:694-701.

5. Hosokawa I, Hosokawa Y, Ozaki K, Yumoto H, Nakae H, Matsuo T: Proinflammatory effects of muramyldipeptide on human gingival fibroblasts. J Periodontal Res 2010, 45:193-199.

6. Mahanonda R, Sa-Ard-lam N, Montreekachon P, Pimkhaokham A, Yongvanichit K, Fukuda MM, Pichyangkul S: IL-8 and IDO expression by human gingival fibroblasts via TLRs. J Immunol 2007, 178:1151-1157.

7. Phipps RP, Borrello MA, Blieden TM: Fibroblast heterogeneity in the periodontium and other tissues. J Periodontal Res 1997, 32:159-165.

8. Birkedal-Hansen H, Moore WG, Bodden MK, Windsor L, Birkedal-Hansen B, DeCarlo A, Engler JA: Matrix metalloproteinases: a review. Crit Rev Oral Biol Med 1993, 4:197-250

9. Hannas AR, Pereira JC, Granjeiro JM, Tjaderhane L: The role of matrix metalloproteinases in the oral environment. Acta Odontol Scand 2007, 65:1-13

10. Sorsa T, Tjaderhane L, Konttinen YT, Lauhio A, Salo T, Lee HM, Golub LM, Brown DL, Mantyla P: Matrix metalloproteinases: contribution to pathogenesis, diagnosis and treatment of periodontal inflammation. Ann Med 2006, 38:306-321.

11. Brew K, Dinakarpandian D, Nagase H: Tissue inhibitors of metalloproteinases: evolution, structure and function. Biochim Biophys Acta 2000, 1477:267-283.

12. Kubota T, Itagaki M, Hoshino C, Nagata M, Morozumi T, Kobayashi T, Takag $\mathrm{R}$, Yoshie $\mathrm{H}$ : Altered gene expression levels of matrix metalloproteinases and their inhibitors in periodontitis-affected gingival tissue. J Periodonto 2008, 79:166-173.

13. Seguier S, Gogly B, Bodineau A, Godeau G, Brousse N: Is collagen breakdown during periodontitis linked to inflammatory cells and expression of matrix metalloproteinases and tissue inhibitors of metalloproteinases in human gingival tissue? J Periodontol 2001, 72:1398-1406.

14. Sorsa T, Tjaderhane L, Salo T: Matrix metalloproteinases (MMPs) in oral diseases. Oral Dis 2004, 10:311-318.

15. Lagente $\mathrm{V}$, Boichot $\mathrm{E}$ : Role of matrix metalloproteinases in the inflammatory process of respiratory diseases. J Mol Cell Cardiol 2010, 48:440-444.

16. Agarwal S, Misra R, Aggarwal A: Induction of metalloproteinases expression by TLR ligands in human fibroblast like synoviocytes from juvenile idiopathic arthritis patients. Indian J Med Res 2010, 131:771-779.

17. Marsh PD: Dental plaque as a biofilm and a microbial community implications for health and disease. BMC Oral Health 2006, 6(Suppl 1):S14.

18. Moore WE, Moore LV: The bacteria of periodontal diseases. Periodontol 1994, 5:66-77.

19. Kerrigan JJ, Mansell JP, Sandy JR: Matrix turnover. J Orthod 2000, 27:227-233.

20. Pattamapun K, Tiranathanagul S, Yongchaitrakul T, Kuwatanasuchat J, Pavasant P: Activation of MMP-2 by Porphyromonas gingivalis in human periodontal ligament cells. J Periodont Res 2003, 38:115-121.

21. Sakaki H, Matsumiya T, Kusumi A, Imaizumi T, Satoh H, Yoshida H, Satoh K, Kimura $\mathrm{H}$ : Interleukin-1 beta induces matrix metalloproteinase-1 expression in cultured human gingival fibroblasts: role of cyclooxygenase-2 and prostaglandin E2. Oral Dis 2004, 10:87-93.

22. Wang L, Zhang ZG, Zhang RL, Gregg SR, Hozeska-Solgot A, LeTourneau Y, Wang Y, Chopp M: Matrix metalloproteinase 2 (MMP2) and MMP9 secreted by erythropoietin-activated endothelial cells promote neural progenitor cell migration. J Neurosci 2006, 26:5996-6003.

23. Domeij H, Yucel-Lindberg T, Modeer T: Signal pathways involved in the production of MMP-1 and MMP-3 in human gingival fibroblasts. Eur $J$ Oral Sci 2002, 110:302-306.

24. Ruwanpura SM, Noguchi K, Ishikawa I: Prostaglandin E2 regulates interleukin-1 beta-induced matrix metalloproteinase- 3 production in human gingival fibroblasts. J Dent Res 2004, 83:260-265.

25. Tewari DS, Qian Y, Tewari M, Pieringer J, Thornton RD, Taub R, Mochan EO: Mechanistic features associated with induction of metalloproteinases in human gingival fibroblasts by interleukin-1. Arch Oral Biol 1994, 39:657-664.

26. Letra A, Silva RM, Rylands RJ, Silveira EM, de Souza AP, Wendell SK, Garlet GP, Vieira AR: MMP3 and TIMP1 variants contribute to chronic periodontitis and may be implicated in disease progression. J Clin Periodontol 2012, 39:707-716.

27. Garlet GP, Martins W Jr, Fonseca BA, Ferreira BR, Silva JS: Matrix metalloproteinases, their physiological inhibitors and osteoclast factors are differentially regulated by the cytokine profile in human periodontal disease. J Clin Periodontol 2004, 31:671-679.

28. Socransky SS, Haffajee AD, Cugini MA, Smith C, Kent RL Jr: Microbial complexes in subgingival plaque. J Clin Periodontol 1998, 25:134-144.

29. Hajishengallis G, Darveau RP, Curtis MA: The keystone-pathogen hypothesis. Nat Rev Microbiol 2012, 10:717-725.

30. Hajishengallis G, Liang S, Payne MA, Hashim A, Jotwani R, Eskan MA, Mclntosh ML, Alsam A, Kirkwood KL, Lambris JD, Darveau RP, Curtis MA: Low-abundance biofilm species orchestrates inflammatory periodontal disease through the commensal microbiota and complement. Cell Host Microbe 2011, 10:497-506.

31. Darveau RP, Hajishengallis G, Curtis MA: Porphyromonas gingivalis as a potential community activist for disease. J Dent Res 2012, 91:816-820.

32. Hajishengallis G: Porphyromonas gingivalis-host interactions: open war or intelligent guerilla tactics? Microbes Infect 2009, 11:637-645.

33. Lamont RJ, Jenkinson HF: Life below the gum line: pathogenic mechanisms of Porphyromonas gingivalis. Microbiol Mol Biol Rev 1998, 62:1244-1263.

34. Ding PH, Wang CY, Darveau RP, Jin LJ: Porphyromonas gingivalis LPS stimulates the expression of LPS-binding protein in human oral keratinocytes in vitro. Innate Immun 2013, 19:66-75.

35. Lu Q, Darveau RP, Samaranayake LP, Wang CY, Jin L: Differential modulation of human $\beta$-defensins expression in human gingival epithelia by Porphyromonas gingivalis lipopolysaccharide with tetraand penta-acylated lipid a structures. Innate Immun 2009, 15:325-335.

36. Andrian E, Grenier D, Rouabhia M: Porphyromonas gingivalis-epithelial cell interactions in periodontitis. J Dent Res 2006, 85:392-403.

37. Kou $Y$, Inaba H, Kato T, Tagashira M, Honma D, Kanda T, Ohtake $Y$, Amano $A$ : Inflammatory responses of gingival epithelial cells stimulated with Porphyromonas gingivalis vesicles are inhibited by hop-associated polyphenols. J Periodontol 2008, 79:174-180

38. Kraus D, Winter J, Jepsen S, Jager A, Meyer R, Deschner J: Interactions of adiponectin and lipopolysaccharide from Porphyromonas gingivalis on human oral epithelial cells. PLoS One 2012, 7:e30716.

39. Andrian E, Grenier D, Rouabhia M: Porphyromonas gingivalis lipopolysaccharide induces shedding of syndecan-1 expressed by gingival epithelial cells. J Cell Physiol 2005, 204:178-183.

40. Hyc A, Osiecka-Iwan A, Niderla-Bielinska J, Moskalewski S: Influence of LPS, TNF, TGF-ss1 and IL-4 on the expression of MMPs, TIMPs and selected cytokines in rat synovial membranes incubated in vitro. Int $\mathrm{J} \mathrm{Mol}$ Med 2011, 27:127-137.

41. Haglund L, Bernier SM, Onnerfjord P, Recklies AD: Proteomic analysis of the LPS-induced stress response in rat chondrocytes reveals induction of innate immune response components in articular cartilage. Matrix Biol 2008, 27:107-118.

42. Santangelo KS, Johnson AL, Ruppert AS, Bertone AL: Effects of hyaluronan treatment on lipopolysaccharide-challenged fibroblast-like synovial cells. Arthritis Res Ther 2007, 9:R1.

43. Castaño JP, Faught WJ, Glavé EE, Russell BS, Frawley LS: Discordance of prolactin gene transcription, mRNA storage, and hormone release in individual mammotropes. Am J Physio/ 1997, 272:390-396.

44. Vogel C, Marcotte EM: Insights into the regulation of protein abundance from proteomic and transcriptomic analyses. Nat Rev Genet 2012, 13:227-232.

45. Alpagot T, Bell C, Lundergan W, Chambers DW, Rudin R: Longitudinal evaluation of GCF MMP-3 and TIMP-1 levels as prognostic factors for progression of periodontitis. J Clin Periodontol 2001, 28:353-359.

46. Haerian A, Adonogianaki E, Mooney J, Manos A, Kinane DF: Effects of treatment on gingival crevicular collagenase, stromelysin and tissue inhibitor of metalloproteinases and their ability to predict response to treatment. J Clin Periodontol 1996, 23:83-91.

47. Nomura T, Ishii A, Oishi Y, Kohma H, Hara K: Tissue inhibitors of metalloproteinases level and collagenase activity in gingival crevicular fluid: the relevance to periodontal diseases. Oral Dis 1998, 4:231-240.

48. Tuter G, Kurtis B, Serdar M, Yucel A, Ayhan E, Karaduman B, Ozcan G: Effects of phase I periodontal treatment on gingival crevicular fluid levels of matrix metalloproteinase-3 and tissue inhibitor of metalloproteinase-1. J Clin Periodontol 2005, 32:1011-1015. 
49. Zhou J, Windsor $\mathrm{U}$ : Porphyromonas gingivalis affects host collagen degradation by affecting expression, activation, and inhibition of matrix metalloproteinases. J Periodont Res 2006, 41:47-54.

50. Kawai T, Akira S: TLR signaling. Semin Immunol 2007, 19:24-32.

51. Takeda K, Akira S: TLR signaling pathways. Semin Immunol 2004, 16:3-9.

52. Cortez DM, Feldman MD, Mummidi S, Valente AJ, Steffensen B, Vincenti M, Barnes JL, Chandrasekar B: IL-17 stimulates MMP-1 expression in primary human cardiac fibroblasts via p38 MAPK- and ERK1/2-dependent C/EBPbeta, NF-kappaB, and AP-1 activation. Am J Physiol Heart Circ Physiol 2007, 293:H3356-H3365.

53. Gao D, Bing C: Macrophage-induced expression and release of matrix metalloproteinase 1 and 3 by human preadipocytes is mediated by IL1 beta via activation of MAPK signaling. J Cell Physiol 2011, 226:2869-2880.

54. Lai WC, Zhou M, Shankavaram U, Peng G, Wahl LM: Differential regulation of lipopolysaccharide-induced monocyte matrix metalloproteinase (MMP)- 1 and MMP-9 by p38 and extracellular signal-regulated kinase 1/2 mitogen-activated protein kinases. J Immunol 2003, 170:6244-6249.

55. McCawley LJ, Li S, Wattenberg EV, Hudson LG: Sustained activation of the mitogen-activated protein kinase pathway. A mechanism underlying receptor tyrosine kinase specificity for matrix metalloproteinase- 9 induction and cell migration. J Biol Chem 1999, 274:4347-4353.

56. Reunanen N, Westermarck J, Hakkinen L, Holmstrom TH, Elo I, Eriksson JE, Kahari VM: Enhancement of fibroblast collagenase (matrix metalloproteinase-1) gene expression by ceramide is mediated by extracellular signal-regulated and stress-activated protein kinase pathways. J Biol Chem 1998, 273:5137-5145.

57. Bond M, Baker AH, Newby AC: Nuclear factor kappaB activity is essential for matrix metalloproteinase- 1 and -3 upregulation in rabbit dermal fibroblasts. Biochem Biophys Res Commun 1999, 264:561-567.

58. Bond $\mathrm{M}$, Chase AJ, Baker AH, Newby AC: Inhibition of transcription factor NF-kappaB reduces matrix metalloproteinase- $1,-3$ and -9 production by vascular smooth muscle cells. Cardiovasc Res 2001, 50:556-565.

59. Fukuda K, Fujitsu Y, Kumagai N, Nishida T: Inhibition of matrix metalloproteinase-3 synthesis in human conjunctival fibroblasts by interleukin-4 or interleukin-13. Invest Ophthalmol Vis Sci 2006, 47:2857-2864.

60. Kajanne R, Miettinen P, Mehlem A, Leivonen SK, Birrer M, Foschi M, Kähäri VM, Leppä S: EGF-R regulates MMP function in fibroblasts through MAPK and AP-1 pathways. J Cell Physiol 2007, 212:489-497.

61. Chase AJ, Bond M, Crook MF, Newby AC: Role of nuclear factor-kappa B activation in metalloproteinase-1, -3 , and -9 secretion by human macrophages in vitro and rabbit foam cells produced in vivo. Arterioscler Thromb Vasc Biol 2002, 22:765-771.

62. Frisch SM, Ruley HE: Transcription from the stromelysin promoter is induced by interleukin-1 and repressed by dexamethasone. J Biol Chem 1987, 262:16300-16304.

63. Al-Qutub MN, Braham PH, Karimi-Naser LM, Liu X, Genco CA, Darveau RP: Hemin-dependent modulation of the lipid A structure of Porphyromonas gingivalis lipopolysaccharide. Infect Immun 2006, 74:4474-4485.

64. Darveau RP, Pham TT, Lemley K, Reife RA, Bainbridge BW, Coats SR, Howald WN, Way SS, Hajjar AM: Porphyromonas gingivalis lipopolysaccharide contains multiple lipid a species that functionally interact with both tolllike receptors 2 and 4. Infect Immun 2004, 72:5041-5051.

65. Manthey CL, Perera PY, Henricson BE, Hamilton TA, Qureshi N, Vogel SN: Endotoxin-induced early gene expression in C3H/HeJ (Lpsd) macrophages. J Immunol 1994, 153:2653-2663.

66. Bainbridge BW, Coats SR, Pham TT, Reife RA, Darveau RP: Expression of a Porphyromonas gingivalis lipid a palmitylacyltransferase in Escherichia coli yields a Chimeric lipid a with altered ability to stimulate interleukin8 secretion. Cell Microbiol 2006, 8:120-129.

67. Di Domenico G, Del Vecchio L, Postiglione L, Ramaglia L: Immunophenotypic analysis of human gingival fibroblasts and its regulation by granulocyte-macrophage colony-stimulating factor (GM-CSF). Minerva Stomatol 2003, 52:87-91.

68. Poggi P, Rodriguez Y, Baena R, Rizzo S, Rota MT: Mouthrinses with alcohol: cytotoxic effects on human gingival fibroblasts in vitro. J Periodontol 2003, 74:623-629.

doi:10.1186/1471-2180-13-73

Cite this article as: Herath et al.: The expression and regulation of matrix metalloproteinase-3 is critically modulated by Porphyromonas gingivalis lipopolysaccharide with heterogeneous lipid A structures in human gingival fibroblasts. BMC Microbiology 2013 13:73.

\section{Submit your next manuscript to BioMed Central and take full advantage of:}

- Convenient online submission

- Thorough peer review

- No space constraints or color figure charges

- Immediate publication on acceptance

- Inclusion in PubMed, CAS, Scopus and Google Scholar

- Research which is freely available for redistribution 